\title{
LEARNING BASED ON THE PROJECT ENTITLED "DESIGN AND CONSTRUCTION OF A WOODEN BRIDGE”
}

\author{
Cristina Barris $\mathbb{D}^{\mathbb{D}}$, Lluís Torres $\mathbb{D}^{\mathbb{D}}$, Enric Simon $\mathbb{D}^{\mathrm{D}}$ \\ Universitat de Girona (Spain) \\ cristina.barris@udg.edu, 1luis.torres@udg.edu, enric.simon@udg.edu
}

Received Januany 2016

Accepted April 2016

\section{Abstract}

This article presents the results of a case involving the application of project-based learning carried out with students in the Mechanical Engineering degree program at the University of Girona. The project, entitled "Design and construction of a wooden bridge", was conducted at the Polytechnic School in the third-year Structures course. This project required students to address, consider and solve different problems related to the resistance of materials, structural calculations, material optimization and structural design. The project also included the building of the bridge based on the calculations made, thus enabling the students to verify the suitability of the theoretical calculations as compared to real results. Furthermore, a competition was held to reward those teams who obtained the best ratio between the failure load and the weight of the bridge. The main conclusion observed from the implementation of only two editions of this project is the acquisition of the different proposed competences (both specific and cross-curricular) by the students. Finally, it was interesting to note that after completing the activity, the students were observed to be more motivated by the course content.

Keywords - Project based learning, Engineering education, Construction. 


\section{Introduction}

Project based learning (PBL) is a learning model in which the students actively work to plan, implement and evaluate real-life projects (Martí, Heydrich, Rojas \& Hernández, 2010; Harwell, 1997). In PBL, learning occurs thanks to the student's effort in carrying out a project proposed by the instructor (Valero-Garcia, 2007). PBL is a specific case in problem based learning (HmeloSilver, 2004). It is especially appropriate in the context of technical subjects, such as engineering (Woods, Felder, Rugarcia \& Stice, 2000), and it has proven to be very useful in order for students to acquire generic competences in a way that is integrated with the specific competences within the scope of the proposed project (Martínez, Amarante, Cadenato \& Rodríguez, 2013). The main advantages of project based learning are, on the one hand, greater student motivation (and as a result, a lower dropout rate and improved academic performance), and on the other, the greater possibility of developing cross-curricular competences and skills (such as the capacity for group work, autonomous learning and effective communication) (Mioduser \& Betzer, 2007). This methodology has previously been successfully applied in other cases involving technical instruction, with varying degrees of involvement of one or more courses (Anguas et al., 2006; Massaguer, González, Montoro \& Ricart, 2013; Barrado et al., 2013).

The present article presents the results of a case of PBL in the Structures course. The course is part of the third-year curriculum in the Mechanical Engineering degree program at the University of Girona (UdG), in the Polytechnic School. It is a 6-credit required course within the Structures and Strength of Materials module. This course covers contents related to structural systems, isostatic and hyperstatic structures, calculation methods based on rigidities, energy methods and the dimensioning of elements subjected to axial and bending stress. In this context, during the 2013-2014 and 2014-2015 academic years, the students were assigned the project entitled "Design and construction of a wooden bridge", in which the main challenge was to apply PBL methodology, and at the same time, to introduce the students to the world of structures from a more applied perspective than that which had been previously used. 


\section{Objectives}

The main objective of this work follows the principles of PBL, in that through solving a problem the student must identify the prior knowledge, needs, resources and actions that are necessary to solve the problem in question, which has no single solution. In the specific case presented in this work, the students were given the task of designing, calculating and building a bridge that would have the greatest ratio between the load or weight resisted and the weight of the bridge itself, as determined by testing.

The project is also intended to check the suitability of the design and calculations made. For this reason, at the end of the course, the previously calculated and constructed bridges are tested up to failure in the structures laboratory at UdG's Polytechnic School. This provides information on the relationship between the theoretical load calculated by the students and the real load. Finally, the activity was also intended to develop different cross-curricular competences, such as the use of information and communications technology, oral and written communication and teamwork. The students were therefore required to present their work via a short oral presentation, accompanied by a poster describing the design, basic calculation hypotheses and results for each bridge.

\section{Development and methodology}

The project was conducted as indicated below. At the beginning of the course, the instructors presented to the students the challenge of designing and building a bar structure in the form of a bridge. Said bridge had to have a minimum of $500-600 \mathrm{~mm}$ between the support points and needed to withstand the maximum load with the minimum possible weight. The bridge was to be built from a specific wood, the mechanical properties of which were provided.

The activity was carried out in teams. The number of students per team varied between three and four, as this was believed to be the optimal number of students so that, on the one hand, it was ensured that everyone participated in the project, and on the other, it did not represent an excessively burdensome task in terms of the number of hours dedicated to building the bridge. Each team was to organize itself and cooperate in order to reach a single optimal solution to the proposed challenge. 
For the students, the focus of the project was similar to a competition. The conditions of this competition attempted to match the observed interests of the participants. At the beginning of the first edition, two clearly differentiated types of students were observed. On the one hand, there was a significant group of students who preferred to work with clearly established guidelines, few variables and a closely regulated work structure. For this group, a "classic" mode of competition was specified, in which most of the requirements were set out beforehand by the instructors. On the other hand, a group of students was identified who were motivated by the opportunity to explore different design typologies and parameters that were not initially considered, unlike the rigidity that characterized the first group. The "innovative" competition mode was created for these students, according to which some of the restrictions that applied to the classic category were eased, encouraging students to make their own decisions, which may or may not follow the established guidelines. This way, each team was assigned to one of the modes, according to their preferences, which resulted in better individual performance and that of the team as a whole. Table 1 contains the main data on participation for the two editions completed so far. Of note is the increase in interest in the innovative category, which increased from $22.2 \%$ the first year to $39.7 \%$ the second year.

\begin{tabular}{|c|r|r|}
\cline { 2 - 3 } \multicolumn{1}{c|}{} & 2013-2014 academic year & 2014-2015 academic year \\
\hline Classic category & & $35(60.3 \%)$ \\
\hline Number of students & 13 & 9 \\
\hline Number of groups & & \\
\hline Innovative category & $12(22.2 \%)$ & $23(39.7 \%)$ \\
\hline Number of students & 4 & 6 \\
\hline Number of groups & & \\
\hline
\end{tabular}

Table 1. Participation data by category

During the course, the professor was responsible for the following tasks: offering guidelines for calculating the structure to be built as appropriate in terms of the course content, monitoring the progress of the group work and redirecting it as necessary.

Specific course competences were addressed during the course of the work, such as:

- Idealization of structures. The concept of translating from a real model to a theoretical one was covered, and the different strategies used to simulate a real case through the knowledge acquired in the course or program were also studied. 
- The design of truss and frame structures and the application of concepts related to strength of materials. The more theoretical concepts involved in the calculation of structures and material resistance, such as stresses, deformations and buckling, were studied from a totally practical perspective.

- Global and local effects. The different responses that can occur in a structure, both globally (structural) and locally (on a bar or joint) were also covered.

Likewise, cross-curricular competences were also considered, such as:

- The rational use of information and communications technologies. During the project, the students used tools related to information technologies, primarily to find information and compare it with their predictions.

- Oral and written communication. Once completed, the project was defended orally in front of the rest of the students' classmates, presenting a poster with the most important information supporting the explanations given.

- Group work. Students were divided up into teams of 3 or 4 people. Each team or group was required to organize and perform all the required tasks.

At the end of the course, each work group presented the bridge they built and a poster that summarized all the relevant information about the bridge design, as well as the calculation hypotheses used and the expected results (the expected total load or stress to be borne and the maximum displacement). During the last week of the course, the students met in a session in which they tested all the bridges, loading them to their failure point (Figure 1 and Figure 2). Parallel to this, during the same session, the posters prepared by the students were exhibited. During the presentation, the students had the opportunity to explain and defend their proposed bridge, and at the same time, observe and learn from the ideas and strategies of the other teams. 


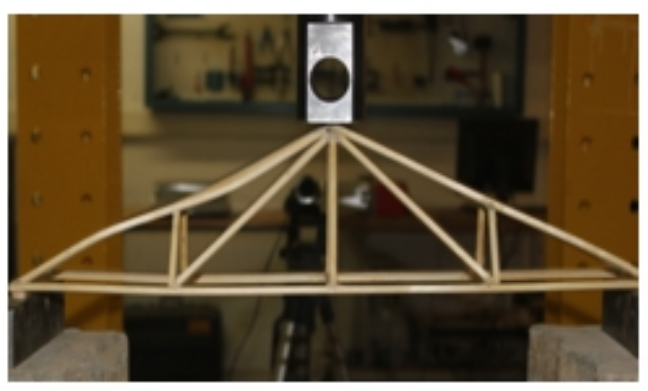

Figure 1. A bridge being tested

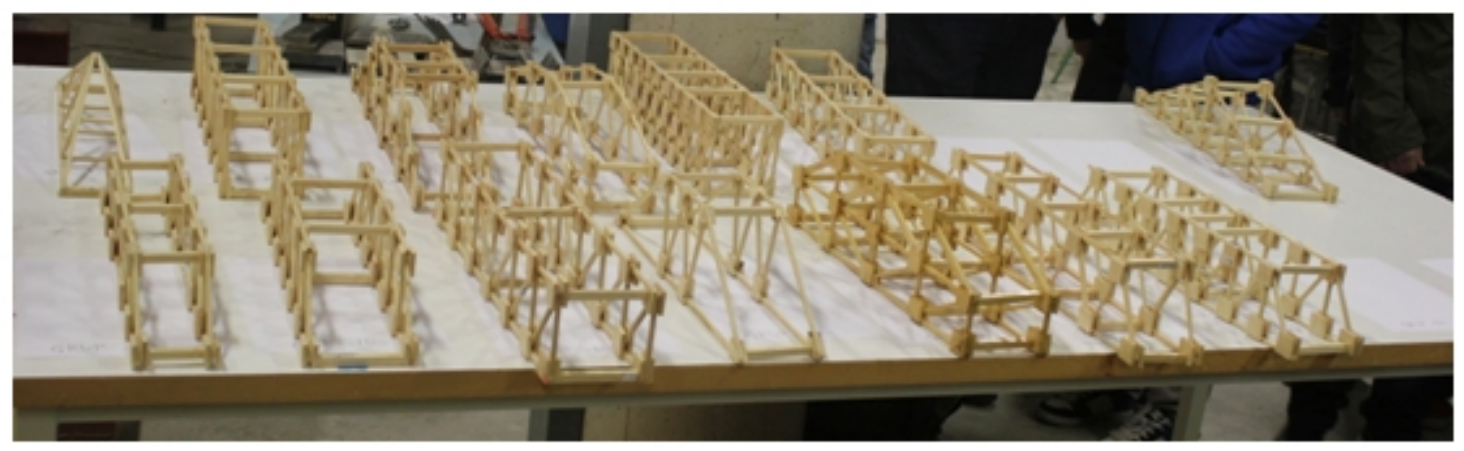

Figure 2. Bridges tested during the first edition of the project

There were two aspects to the project evaluation. On the one hand, the activity was evaluated based on the poster and oral presentation given by each team of students. This score formed part of the total course grade. On the other hand, the teams were rewarded that obtained the best experimental result, understood as the effectiveness ratio of the maximum load supported by the bridge and its own weight. The reward consisted of extra points on the final exam, as long as at least 4 points over 10 were earned on the exam. The three best teams in each category (classic and innovative) were rewarded. Table 2 shows the results of the effectiveness ratio for the two editions held so far. It can be observed that the result in the classic category increased from 0.77 to 0.84 , while the result in the innovative category dropped, due to an exceptional result of 1.55 obtained in the first edition of the project. 


\begin{tabular}{|c|r|r|}
\cline { 2 - 3 } \multicolumn{1}{c|}{} & 2013-2014 academic year & 2014-2015 academic year \\
\hline Classic category & 0.77 & 0.84 \\
\hline Best result & & \\
\hline Innovative category & 1.55 & 0.70 \\
\hline Best result & & \\
\hline
\end{tabular}

Table 2. Ratio load supported/weight of the bridge

At the end of the activity, an opinion survey was administered to the different groups, asking about their degree of overall satisfaction. An average of $85 \%$ of the students assessed the initiative very positively. Likewise, the students were asked in a general sense about the different aspects they would highlight about the experience. The responses were varied, with a fairly generalized perception that it led to better comprehension of the importance of aspects like buckling (local and global) and the importance of joints and the correct modelling of the physical element (or vice versa, the proper construction of the modelled element). The option to participate in the innovative category was also mentioned.

Finally, the following quarter after the course was finished, the posters and bridges were put on display in the hall of the building where the Mechanical Engineering degree program is taught, so that students from other years could see the results of their classmates.

\section{Conclusions}

During the 2014-2015 academic year, a second edition of the "Design and construction of a wooden bridge" project was held in the Structures course as part of the Mechanical Engineering degree program at the University of Girona. From the experience obtained from two editions in two consecutive academic years, the main conclusion has been that we have been successful in implementing PBL methodology in the mentioned Structures course at the University of Girona. Likewise, the students have met expectations regarding the specific competences proposed. It was finally indicated that the cross-curricular competences proposed had been adequately addressed.

In summary, the results obtained from the two editions held have been very satisfactory. The students have reached the proposed objectives and have even exceeded, in some cases, the learning perspectives anticipated by the professors. Subsequent surveys have demonstrated a high level of motivation and satisfaction by the students. 
Furthermore, it has been shown that this methodology requires greater effort by the instructors in terms of planning, anticipating possible setbacks that might occur, orientation and guidance. In addition, in these first editions, certain aspects were detected that had room for improvement, such as the types of joints created, the calculation of a specific element and the calculation of deformations, for example.

This project is expected to be used in the future as a learning method in this course, given the good results obtained so far.

\section{References}

Anguas, J., Díaz, L., Gallego, I., Lavado, C., Reyes, A., Rodríguez, E. et al. (2006). Una experiencia de adaptación al EEES de dos asignaturas de programación de ordenadores. Congreso Internacional de Docencia Universitaria e Innovación. Available online at: http://www.xtec.cat/aulatec/Experiencia EEES.pdf

Barrado, C., Cuadrado, R., Delgado, L, Mellibovsky, F., Pastor, E., Pérez et al. (2013). Una experiencia de unificación de asignaturas para desplegar PBL (y las quejas que originó). ReVisión, 6(2), 50-59.

Harwell, S. (1997). Project-based learing. In: W.E. Blank \& S. Harwell (Eds), Promising practices for connecting high school to real word (pp. 23-28). Tampa, Florida: University of South Florida.

Hmelo-Silver, C.E. (2004). Problem-Based Learning: What and How Do Students Learn?. Educational Psychology Review, 16(3):235-266. http://dx.doi.org/10.1023/B:EDPR.0000034022.16470.f3

Martí, J., Heydrich, M., Rojas, M., \& Hernández, A. (2010). Aprendizaje basado en proyectos: Una experiencia de innovación docente. Revista Universidad EAFIT, 45(158), 11-21.

Martínez, M., Amarante, B., Cadenato, A., \& Rodríguez, R. (2013). Una propuesta de evaluación de competencias genéricas en grados de Ingeniería. REDU - Revista de Docencia Universitaria, 11(Número especial dedicado a Engineering Education), 113-139.

Massaguer, E., González, J.R., Montoro, L., \& Ricart, J. (2013). Aprenentatge basat en projectes col·laboratius (CPBL) dins l'assignatura d'instal-lacions de climatització del grau en enginyeria mecànica. IV Congrés Internacional Univest 2013. Available online at: http://dugidoc.udg.edu/handle/10256/8119 
Mioduser, D., Betzer, N. (2007). The contribution of Project-based-learning to high-achievers' acquisition of technological knowledge and skills. International Journal of Technology and Design Education, 18, 59-77. http://dx.doi.org/10.1007/s10798-006-9010-4

Valero-García, M. (2007). L'aprenentatge basat en projectes en els ensenyaments tècnics. Perspectiva Escolar, 318. Available online at:

http://epsc.upc.edu/projectes/usuaris/miguel.valero/materiales/docencia/articulos/perspectiva escolar.pdf

Woods, D.R., Felder, R.M., Rugarcia, A., \& Stice, J.E. (2000). The future of engineering education. Developing critical skills. Chemical Engineering Education, 34(2), 108-117.

Published by OmniaScience (www.omniascience.com)

Journal of Technology and Science Education, 2016 (www.jotse.org)

\section{(c)}

SOMERIGHIS RESERVED

Article's contents are provided on an Attribution-Non Commercial 3.0 Creative commons license. Readers are allowed to copy, distribute and communicate article's contents, provided the author's and JOTSE journal's names are included. It must not be used for commercial purposes. To see the complete licence contents, please visit http://creativecommons.org/licenses/by-nc/3.0/es/ 